\title{
Discussion: Civil engineering heritage: country profile - Belgium
}

Bernard Espion MCEng, DrEng

Professor, BATir Department, Université Libre de Bruxelles, Brussels, Belgium (corresponding author: bespion@ulb.ac.be)

Robin Engels MArchEng, MConservation

Engineer, Origin Architecture \& Engineering, Brussels, Belgium
Michel Provost MCEng

Professor, BATir Department, Université Libre de Bruxelles, Brussels, Belgium; Associate, Origin Architecture \& Engineering, Brussels, Belgium Ian Anderson BSC, CEng, MICE, MIStructE

East of England member, ICE Panel for Historical Engineering Works, UK

\section{Contribution by I. Anderson}

The contributor very much enjoyed reading the country profile on Belgium in Engineering History \& Heritage and would like to add the early hangars at Melsbroek-Brussels Airport, and the circular hangars at Grimbergen, as well as other early post-World War 2 (WW2) prestressed-concrete structures in Belgium, all of which are significant civil engineering heritage sites that are worthy of note.

\section{Melsbroek-Brussels Airport, Hangar 2}

The Melsbroek Hangar 2 in particular is of interest in that it comprises long-span, prestressed-concrete beams over the four bays, constructed c. 1948 (Duyster, 1948, 1949a, 1949b; Harris and Morice, 1952; Magnel, 1949, 1950; Novgorodsky, 1954). Each bay has four beams of $165 \mathrm{ft}(50 \mathrm{~m})$ span at $33 \mathrm{ft}(10 \mathrm{~m})$ centres of $8 \mathrm{ft}(2.4 \mathrm{~m})$ depth. Each beam is of box-girder shape with internal Magnel-Blaton prestressing cables. The front beam over the doors is rectangular and the other three are trapezoidal. Each beam was constructed on the ground and jacked into place using temporary ladders fixed to the sides of the columns. Caston-site reinforced-concrete roof slabs span front to back on the main beams.

\section{Grimbergen mushroom hangars}

The two circular aircraft hangars were originally described in La Technique des Travaux for January-February 1952, as in UK (Anon., 1953a, 1953b). The roof is a circular concrete shell of $164 \mathrm{ft}(48.7 \mathrm{~m})$ dia. and maximum height of $23 \mathrm{ft}(7 \mathrm{~m})$. It comprises a central dome of $72 \mathrm{ft}(22 \mathrm{~m})$ dia. supported on four double columns around the perimeter, with an outer cantilevered $46 \mathrm{ft}(14 \mathrm{~m})$ beyond the columns. Roof thickness varies between 3 inches $(76 \mathrm{~mm})$ in the central dome to 4.75 inches $(120 \mathrm{~mm})$ in the outer cantilever. The hangar is closed by sliding doors covering the $490 \mathrm{ft}(149 \mathrm{~m})$ circumference. The design was by M. Hardy of Quievrain, the engineers were Blaton-Aubert of Brussels.

\section{Other early post-WW2 prestressed-concrete structures in Belgium}

Professor Gustave Magnel lists various applications of prestressed concrete in his 1949 paper (Magnel, 1949). These include a railway bridge in Brussels, road bridges at Eecloo and Ghent, a footbridge at Malheyre, textile factories in Brussels and Ghent, cement silos at Tournai, spun-concrete pressure pipes and underpinning works as well as hangars at Rotterdam and Melsbroek, as above.

\section{Author's reply}

The authors express their sincere thanks to the contributor for his interest in their paper and his suggestions for some interesting structures to add to the country profile for Belgium.

Significantly, the contributor suggests some structures that were built in a very short period of time (1943-1953), which are all somehow connected with Professor Gustave Magnel and which all, but one, belong to the early phase of development of prestressed concrete in Belgium. This testifies to the international recognition given to the pioneering work of Professor Magnel (18891955), who, with the Brussels-based contractor Blaton-Aubert, effectively developed during WW2 a system of anchorages and cables consisting of $5 \mathrm{~mm}$ dia. high-strength steel wires to apply prestressing forces to a concrete structure by post-tensioning. That system is known by the name 'Magnel-Blaton' or 'Sandwich'. Initially, this system of post-tensioning (patented in March 1942) was developed with the consent of Eugène Freyssinet, because the Freyssinet system was not available in Belgium in wartime conditions (Espion, 2015).

All of the prestressed-concrete structures cited by the contributor are described, sometimes only briefly, in the book written by Professor Magnel on prestressed-concrete design (Magnel, 1948, 1950, 1954). The descriptions in Magnel's book generally indicate some form of personal involvement by Magnel himself in the promotion or even in the conceptual design of these structures. This has been firmly established by the author in his analysis of the archives of the Blaton-Aubert company, which have recently (since 2013) been opened to research for the period 1900-1954 (Espion and Hellebois, 2017).

The book written by Professor Magnel, published in English in 1948, was the first practical manual dealing with the detailed design of prestressed-concrete structures. The first edition (Magnel, 1948) gives a quasi-exclusive account of the structures tested by Professor Magnel in his laboratory at Ghent University from 1941 or built at that time using the Sandwich system. In parallel, after 1945 , the Blaton-Aubert company was rapidly trying to promote the Belgian Sandwich system outside of Belgium, in competition with the Freyssinet system promoted worldwide by STUP. Notably, the Sandwich system was quickly taken up in the UK (Burgoyne, 2005). 
The publication of a book in English, firstly in the UK (Magnel 1948, 1950), and later in the US (Magnel, 1954), and the successful promotion of the Sandwich system outside Belgium, probably explains why the structures mentioned by the contributor are well known and can rank as notable civil engineering heritage structures in Belgium. The authors had felt that it was only worth mentioning within this category of structure the seminal application of the experimental railway bridge decks at the Rue du Miroir in Brussels in 1943 in order to achieve an appropriate balance between all kinds of civil engineering works and structures over a period of two centuries in their paper.

Some of the early prestressed-concrete structures from that period still exist. Besides the railway bridge in Brussels and the underpinning foundations of the Pont des Trous already cited in the paper, there are also the following structures.

- The footbridge at Malheide, which, in fact, was not built according to the design by Magnel and Blaton-Aubert (Magnel, 1948) but to a design by the engineer Carlos Wets using high-strength steel bars (Espion, 2009).

- The cement silos at Tournai with their connecting footbridge, built in 1943 (Espion, 2015). After several years of disuse, they are now awaiting a probable reconversion into apartments.

- The $20 \mathrm{~m}$ span roof (covering $3000 \mathrm{~m}^{2}$ ) of the Chevrolet garage in Brussels (1949) built by Blaton-Aubert with architects Charles Malcause and Robert Puttemans.
Some of the most interesting prestressed-concrete structures from that period have been lost, or are about to be demolished.

- The roof of the Union Cotonnière (UCO) textile mills in Ghent (1948), which covered nearly $30000 \mathrm{~m}^{2}$ using a grid of prestressed-concrete beams built by Blaton-Aubert.

- A footbridge (21 m span) built across the canal in Brussels in Autumn 1944 by the contractor Eng. G. Clauses with Blaton-Aubert as supplier for prestressing operations (Espion, 2009, 2015).

In both cases, a scientific experimental programme is currently being undertaken (at Ghent University for the UCO mills, and the University of Brussels for the footbridge) to assess the durability, the reliability and residual load capacity of these early prestressedconcrete structures.

It is also interesting to recall here that many of the early structures designed by Magnel were applications of post-tensioning by external prestressing. This was, in particular, the case for the huge beams built to cover the Melsbroeck hangar mentioned by the contributor. In fact, they were not built by Blaton-Aubert, but by the company Strabed using Sandwich technology for post-tensioning. To the best knowledge of the authors, these hangars unfortunately no longer exist. But the technology of external prestressing using Sandwich cables, in which the cables can be seen running into the caisson of hollow beams, was used to construct several bridges in Belgium.

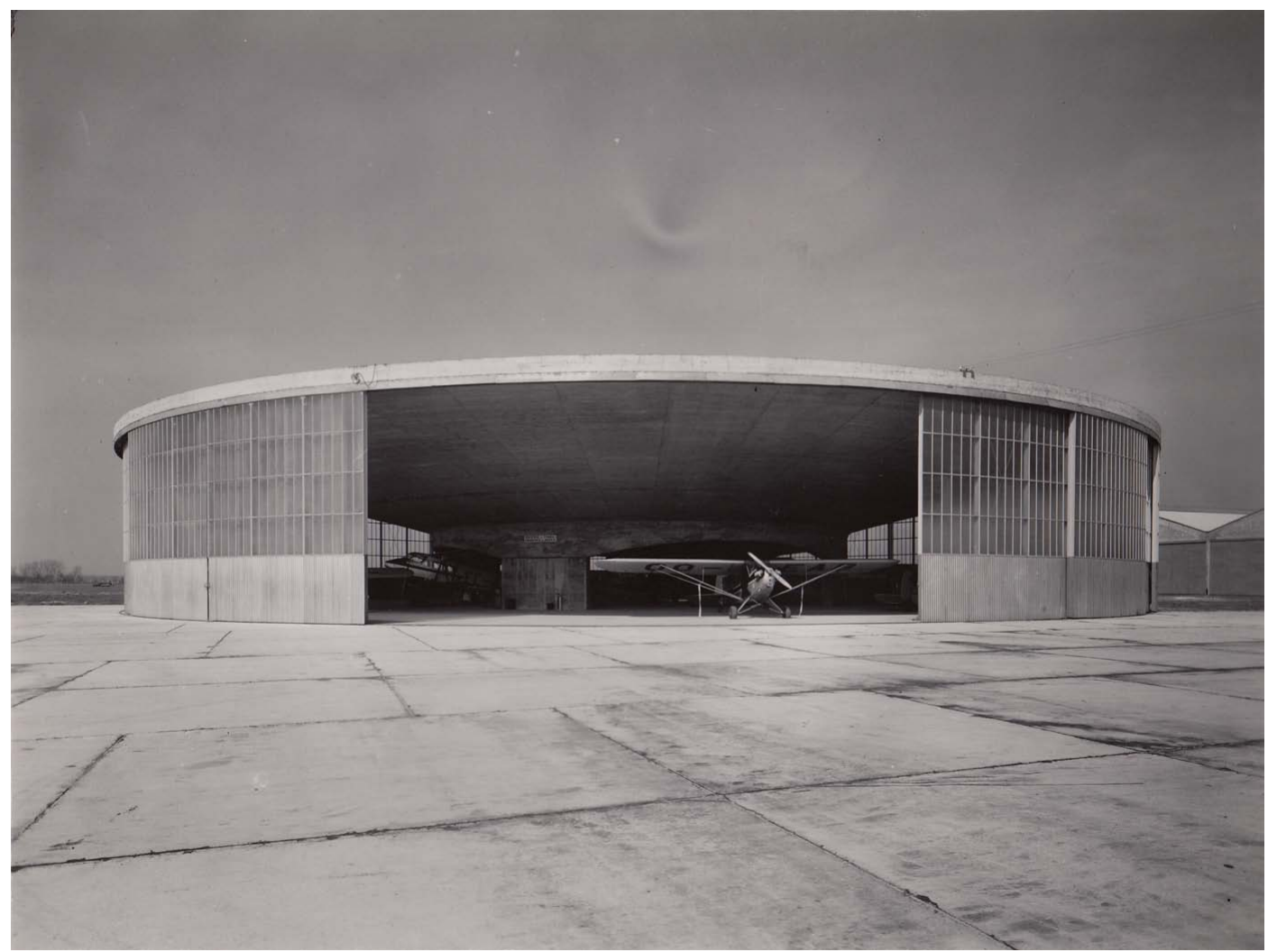

Figure 7. Circular aircraft hangars at Grimbergen 
Engineering History and Heritage

Volume 171 Issue EH1
Discussion

Espion, Engels, Provost and Anderson
The best known is probably the bridge crossing the Meuse river at Sclayn, built in 1949 by Blaton-Aubert (Magnel, 1950). This was the first two-span continuous beam bridge built in the world and could certainly feature on a list of landmark structures. The general concept most likely came from Magnel, but the detailed design was performed by the engineer Alexandre Birguer. The prestressing tendons in that bridge were replaced in 1990, and the author is aware of at least five other bridges built in Belgium before 1960 with external prestressing, where the corroded tendons had to be replaced, which was not always straightforward (Rammer and Espion, 2014).

Finally, the contributor suggests adding the circular aircraft hangars at Grimbergen (Figure 7). They still exist. They were built by Blaton-Aubert with the support of Magnel, but according to a design patented by Alfred Hardy, who was an inventor rather than a reinforced-concrete engineer. The story of this structural type, of which the Grimbergen hangars were the largest built, has been told in detail by Strauven (2002). It should be underlined that they were not prestressed. For the authors, they merely represent a structural curiosity; they would hardly find a place in the story of thin concrete shells. However, it should be noted that they were the only Belgian structures illustrated in the catalogue of the exhibition on Twentieth Century Engineering held at the Museum of Modern Art in New York, USA, in 1964 (Drexler, 1964), which, by itself, constitutes an international recognition of their 'civil engineering heritage' status.

\section{REFERENCES}

Anon. (1949) Prestressed concrete in Belgium. Concrete Quarterly 6: $8-15$.

Anon. (1953a) Circular reinforced concrete hangars. Concrete and Constructional Engineering 48: 124-125.

Anon. (1953b) Circular cantilevers roof two "Mushroom hangars". Concrete Quarterly 17: 21.

Burgoyne C (2005) Early applications of prestressed concrete in the United Kingdom. In Proceedings of the Ned H Burns Symposium on Historic Innovations in Prestressed Concrete (Russell BW and Gross SP (eds)). SP-231, American Concrete Institute, Farmington Hills, MI, USA, pp. 15-32.
Drexler A (1964) Twentieth Century Engineering. The Museum of Modern Art, New York, NY, USA. See https://www.moma.org/documents/ moma_catalogue_2568_300190129.pdf (accessed 05/02/2018).

Duyster HC (1948) Les hangars en béton précontraint de l'aérodrome de Bruxelles-Melsbroek. La Technique des Travaux 1948(9/10): 285-296 (in French).

Duyster HC (1949a) Prestressed concrete girders for large span hangar roof at Brussels Airport. Building Digest, January, p. 16.

Duyster HC (1949b) The construction of aircraft hangars with spans of $164 \mathrm{ft}$ and $377 \mathrm{ft}$ in prestressed concrete at the Melsbroek airfield near Brussels (translation from the Dutch and reprinted from De Ingenieur 61(18): 1-32). Cement \& Concrete Association, Camberley, UK, No.12.

Espion B (2009) Early applications of prestressing to bridges and footbridges in Brussels area. In Proceedings of the Third International Congress on Construction History, Cottbus, Germany (KE Kurrer, W Lorenz and V Wetzk (eds)). Neunplus1, Berlin, Germany, pp. 535-541.

Espion B (2015) The founding events of prestressed concrete in Belgium seen through the Blaton archives. In Proceedings of the 5th International Congress on Construction History (Bowen B, Friedman D, Leslie T and Ochsendorf J (eds)), Construction History Society of America, vol. 2, pp. 41-48.

Espion B and Hellebois A (2017) Blaton et l'innovation technologique/Blaton en technologische innovatie. In Blaton. Une Dynastie de Constructeurs/ Een Dynastie van Bouwers (Pesztat Y (ed.)). AAM Éditions/Fondation CIVA, Brussels, Belgium, pp. 62-107 (in French and Dutch).

Harris JD and Morice PB (1952) Prestressed Concrete. Cement \& Concrete Association, Camberley, UK.

Magnel G (1948) Prestressed Concrete, 1st edn. Concrete Publications, London, UK.

Magnel G (1949) Applications of prestressed concrete in Belgium. Proceedings of the Institution of Civil Engineers 32(6): 161-174.

Magnel G (1950) Prestressed Concrete, 2nd edn. Concrete Publications, London, UK

Magnel G (1954) Prestressed Concrete, 3rd edn. McGraw-Hill, New York, NY, USA.

Novgorodsky L (1954) Les hangars de l'aeroport de Melsbroak-lezBruxelles. La Technique des Travaux 1954(9/10): 285-306 (in French).

Rammer Y and Espion B (2014) A case study of replacement of external post-tensioning cables. Proceedings of the Institution of Civil Engineers - Bridge Engineering 167(3): 183-192, https://doi. org/10.1680/bren.13.00019.

Strauven I (2002) Alfred Hardy 1900-1956. Ghent University Architectural and Engineering Press, Ghent, Belgium (in Dutch). 